\title{
MITIGATION OF LOW TEMPERATURE STRESS BY POLYTHENE FOR QUALITY PRODUCTION OF GLADIOLUS (Gladiolus hortulanus L.) DURING WINTER
}

\author{
QAYYUM, M. M. ${ }^{1 *}-$ HASSAN, I. ${ }^{1}-$ ABBASI, N. A. ${ }^{1}-$ KHALID, A. ${ }^{2}$ \\ ${ }^{I}$ Department of Horticulture, Pir Mehr Ali Shah Arid Agriculture University, Rawalpindi, \\ Pakistan \\ ${ }^{2}$ Department of Environmental Science, Pir Mehr Ali Shah Arid Agriculture University, \\ Rawalpindi, Pakistan \\ *Corresponding author \\ e-mail: mazhar.hort.aup@gmail.com \\ (Received $16^{\text {th }}$ Dec 2019; accepted 20 $0^{\text {th }}$ Mar 2020)
}

\begin{abstract}
Temperature plays a crucial role in growth rate and development of a plant. Low temperature damages plant metabolic processes. The poly tunnel is used to mitigate low temperature stress for quality production of gladiolus. The Randomized complete block design with two factors factorial was used to carry this experiment. Protective field conditions enhanced temperature level that resulted in longer spike length, higher number of leaves per plant, more leaf area, maximum spike diameter, more number of florets per spike, larger diameter of flower, more fresh and dry weight, higher photosynthetic rate and less days to taken flowering, were obtained during November and December under poly tunnel conditions. Chlorophyll contents and transpiration rate significantly increased during early warmer months. Stomatal conductance not significantly changes. More antioxidant enzyme (POD and CAT) activity was recorded and less electrolyte leakage due to which vase life remained higher in November and December under protective planting conditions. Moreover, gladiolus cut flowers quality features were significantly improved in protective growing conditions in poly tunnel during January and February. Protective growing conditions mitigated low temperature stress in cold months and significantly enhanced yield as well as quality characteristics of gladiolus cut flowers.
\end{abstract}

Keywords: antioxidant enzymes, protected cultivation, prolonged season, temperature stress, vase life

\section{Introduction}

Gladiolus (Gladiolus hortulanus L.) among the cut flowers stands second in term of production and consumers' predilection. Gladiolus with imperial spikes is one of the most common and well-known cut flowers in the world that encompass striking, elegant and elusive florets (Saeed et al., 2013). It has virtuous keeping ability because its florets open in an order for extended period. It is often used in bouquets, bedding, landscape, flower arrangement etc. (Arora, 2007). It has occupied an area of 7,384.34 ha worldwide with a trade worth of US \$3,100 million. The Netherlands shares $48.5 \%$ and Germany $45.3 \%$ in world trade (Ahmad and Rab, 2020). Commercial gladiolus production not only generates good profits, but can also earn foreign exchange. The length of spike, florets count, intact flower quality, freshness of flower, and vase life are major market indices. Therefore, superfluous attention is given to quality of flower rather than its production (Bhande et al., 2015). A key factor to the aesthetic and marketable quality is the postharvest longevity of cut flowers (Saeed et al., 2013). Preharvest growth circumstances determine ultimate postharvest fate of flower. The gladiolus life cycle is divided in two phases. The first phase is vegetative growth and second is flower initiation and development. These phases are characterized by several processes, viz., cellular 
division, differentiation, expansion and eventual petal senescence. Therefore, it is need for prodigious attention to enhance all the physiological and biochemical processes that occur during flower growth and development (Sood et al., 2006).

Plant growth and crop productivity is badly affected by low temperature stress that leads to considerable damages in production of crops (Jiang, 2011). The consequences of low temperature stress since temperatures cool enough to induce damages within tissues of plant. The level of tolerance to freezing $\left(<0^{\circ} \mathrm{C}\right)$ and chilling $\left(0-15^{\circ} \mathrm{C}\right)$ temperature ranges are specific to different plant species. The cold stress or low temperature stress includes chilling and freezing stress. The growth features of crop plants include rate of survival, water balance, transportation, cell division and development, and photosynthesis, all of them are affected by low temperature stress (Sanghera et al., 2011). Plant growth rate depends upon ranges of ambient temperature of the crop species. Therefore, every plant species have a precise level of least, extreme and optimal temperature range (Hatfield et al., 2011). Proper growth and development of gladiolus depend on abundant light, appropriate temperature and plenty of soil moisture. Gladiolus plants prefer a temperature regime between $12-20^{\circ} \mathrm{C}$ (Khodorova and Boitel-Conti, 2013). The selected progenies of gladiolus are hardy to $-6^{\circ} \mathrm{C}$ that is not within minimum range required in USDA Z3-4 (Anderson et al., 2012). The low temperature below $10^{\circ} \mathrm{C}$ causes an arrest in growth and development of the plant (Mayoli and Isutsa, 2012). The plant metabolic processes and development of whole plant, tissues, cells and even at subcellular levels are distraught by low temperatures. The morphology, anatomy, phenology and plant biochemistry at all levels of organization also may affected by temperature variation (Porter, 2005; Waraich et al., 2012). The leaf initiation, enlargement and flowering are totally temperature dependent. Also growth and development of plants primarily influence by air temperature of the growing environment (von Caemmerer and Evans, 2015). The stress induced by low temperature influenced the vegetative as well as reproductive stages in the plant's life cycle. The different characteristics like flower initiation, abscission, pollen sterility, pollen tube distortion, and ovule abortion during reproductive development inversely affected by low temperature stress that eventually reduced the production (Khodorova and Boitel-Conti, 2013).

There are various strategies which are being used to mitigate the detrimental effects of low temperature stress. The polythene tunnel cultivation is used as one approach to mitigate the damaging effects of low temperature that is most suitable for growing high value horticultural crops (Hanan, 2017). Polythene house is an enclosed structure protected with polyethylene sheet which might provide the promising environments intended for the better growth of the plants in numerous ways, viz., shield from hostile ecological circumstances, protection from heavy winds, pests, diseases and other antagonistic weather conditions (Cowan et al., 2014). Agro-meteorological indices and temperature sensitivity of gladiolus are directly affected in low temperature stressed circumstances, which is yet to be studied. In present research, an exertion was made to evaluate the morpho-physiological in relation to low temperature stress and mitigation of effects for quality cut flower production.

\section{Materials and Methods}

The study was carried out at Horticulture department research area in PMAS Arid Agriculture University, Rawalpindi, Pakistan (Latitude: 3338'51", Longitude: 73'57.72"), during 2013-2014 and 2014-2015. The corms of the gladiolus cultivar 
"White Prosperity" were planted on monthly interval basis during months (November, December, January and February) in open field conditions to check the low temperature effects and in Poly tunnel conditions to evaluate the mitigation effects. Randomized complete block design (RCBD) with two factors factorial. The growing conditions were factor one and planting times were second factor. The corms were planted in sand bed for uniform germination and planted in research area when they reached up to $10-15 \mathrm{~cm}$ in height. The corms were transplanted at a row to row distance of $30 \mathrm{~cm}$ while distance of $20 \mathrm{~cm}$ was kept between two plants in a raised bed. The experiment was carried in a randomized complete block design replicated thrice. The five plants were randomly selected for each observation. Before the plantation of corms well rotten farm yard manure was mix in soil. The tunnel was covered with $0.6 \mathrm{~mm}$ thick polythene sheet and tunnel dimensions were $12 \mathrm{~m}$ long, $3 \mathrm{~m}$ wide and $2.5 \mathrm{~m}$ high. Data regarding temperature and relative humidity was noticed two times in a day for both in open field and inside polythene tunnel (Figure 1). Other cultural operations like irrigation, fertilization, weeding, and plant protection measures were alike for all treatments. The data was recorded separately for every month from date of sowing for following characteristics.

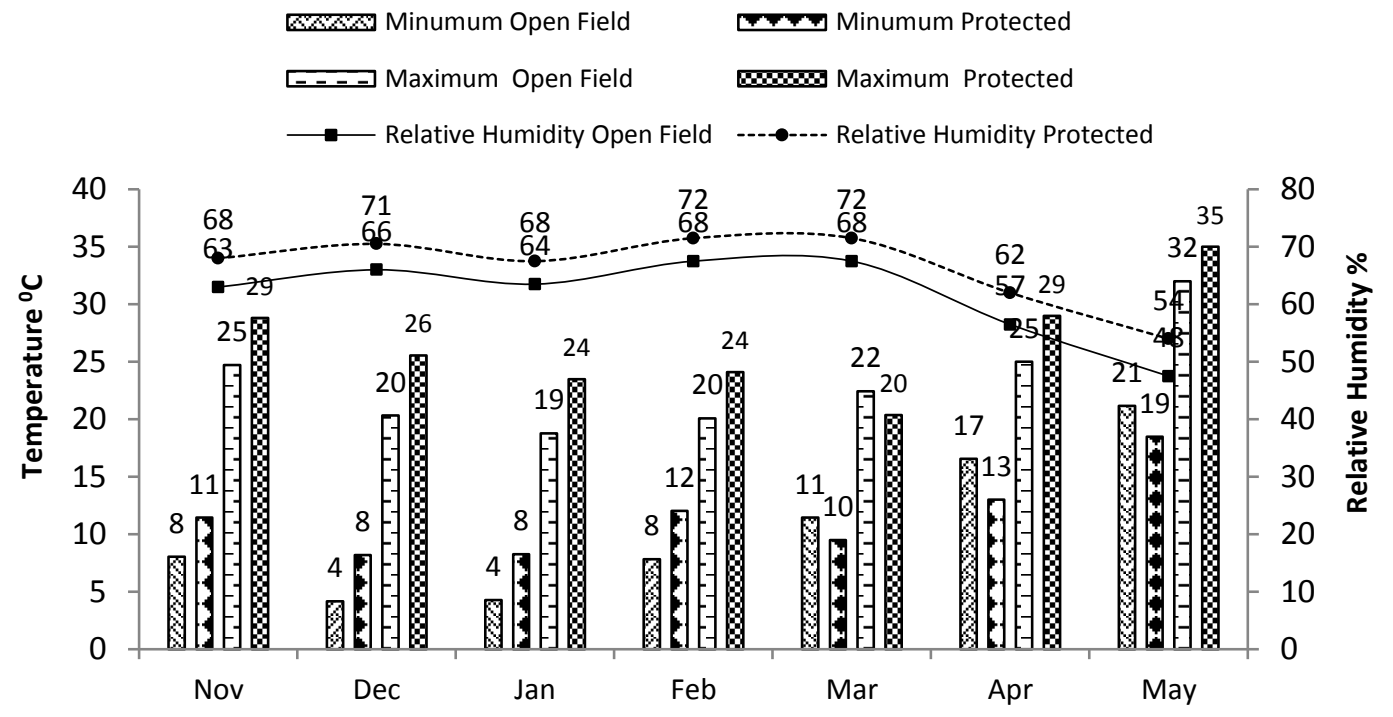

Figure 1. Average weather data during study period

\section{Morphological and floral characteristics}

Data on number of plant height $(\mathrm{cm})$, leaves plant ${ }^{-1}$, leaf area $\left(\mathrm{cm}^{2}\right)$, number of days taken to flowering from date of sowing for each month, number of cormels plant ${ }^{-1}$, corm diameter $(\mathrm{cm})$, corm weight $(\mathrm{g})$, spike length $(\mathrm{cm})$, spike thickness $(\mathrm{mm})$, number of florets spike ${ }^{-1}$, flower diameter $(\mathrm{cm})$ and fresh weight of spike were recorded at harvest stage.

\section{Vase life parameters}

There were three cut spikes placed in vase for vase life attributes in every replication. Percentage of florets opened, days to open florets, and vase life were recorded put in vase. 


\section{Bio-chemical attribute}

Spade meter (SPAD 502 Konica Minolta, Japan) used for determining chlorophyll contents in plant leaves.

\section{Physiological characteristics}

Photosynthetic rate, transpiration rate and stomatal conductance were measured according to the method described by Long and Bernacchi (2003). LCA-4 ADC portable infrared gas analyzer (Analytical Development Company, Hoddesdon, England) was used between the hours of 12:00 and 15:00 at the prevailing solar radiation on flowering stage.

\section{Relative water content}

Relative water content (RWC) was determined according to the method given by Bars and Weatherley (1962). Leaves were excised and fresh weight (FW) was immediately recorded then leaves were soaked for $4 \mathrm{~h}$ in distilled water at room temperature and turgid weight (TW) was recorded. After drying for $24 \mathrm{~h}$ at $80^{\circ} \mathrm{C}$, dry weight (DW) was recorded. The RWC was calculated as follows:

$$
R W C(\%)=\frac{(F W-D W)}{(T W-D W)} \times 100
$$

\section{Electrolyte leakage (EL)}

Electrolyte leakage was calculated using the procedure quoted by Singh et al. (2008) with minor modification. Five floral petal discs with a diameter of $10 \mathrm{~mm}$ from each treatment were put together in a test tube containing $10 \mathrm{~mL}$ of distilled water. Initially leakage of membrane was measured with a conductivity meter after incubation at $25^{\circ} \mathrm{C}$ for $180 \mathrm{~min}$ of that test tube. Before the final conductivity was measured, solution was boiled for $10 \mathrm{~min}$ in a water bath to release all the electrolytes.

The leakage of the membrane was measured as below:

$$
E L(\%)=\frac{C 1}{C 2} \times 100
$$

where, $\mathrm{C} 1$ is electrical conductivity of petals after $180 \mathrm{~min}$ incubation in room and $\mathrm{C} 2$ is final electrical conductivity of the solution.

\section{Enzyme extracts preparation}

Flowers were frozen in liquid nitrogen and one gram sample was carried from every replication. The sample was grinded in pre-cold mortar and pestle. The floral tissues were precipitated in $5 \mathrm{~mL}$ of $0.1 \mathrm{M} \mathrm{KPO} 4$ buffer ( $\mathrm{pH} 7.8$ ) having $0.5 \%$ Triton and $0.2 \mathrm{~g}$ of PVPP. The prepared mixture was centrifuged for $30 \mathrm{~min}$ at $4^{\circ} \mathrm{C}$ at $27,000 \times \mathrm{g}$ (Abbasi et al., 1998). 


\section{Assessment of peroxidase}

The activity of peroxidase (POD) was tested with minor changes according to the procedure described by Shaheen et al. (2015). The mixture of assay comprised of $1 \mathrm{mM}$ $\mathrm{H}_{2} \mathrm{O}_{2}, 0.1 \mathrm{mM}$ guaiacol in $15 \mathrm{~m} \mathrm{MNaKPO}_{4}$ buffer $(\mathrm{pH}$ 6.0) and $200 \mu \mathrm{L}$ basic extract of enzymes. The activity of POD was noted as a change in the optical density (OD) over a three min period at $470 \mathrm{~nm}$ and measured as unit $\mathrm{g}^{-1}$ fresh weight.

\section{Catalase assessment}

The activity of catalase (CAT) was tested according to the procedure with slight changes used by Saeed et al. (2013). Two buffer solutions were used to start reaction, one holding $50 \mathrm{mM} \mathrm{KPO}_{4}$ and second comprising of $12.5 \mathrm{mM} \mathrm{H}_{2} \mathrm{O}_{2}$ in $50 \mathrm{mM} \mathrm{KPO}_{4}(\mathrm{pH} 7.0)$. The $300 \mu \mathrm{L}$ enzyme to each buffer added in $3 \mathrm{~mL}$ cuvettes for reaction was started, and OD was noted at $240 \mathrm{~nm}$. The unit for catalase activity was unit $\mathrm{g}^{-1}$ fresh weight.

\section{Statistical analysis}

The statistically analysis of data was carried out by ANOVA technique in Randomized complete block design (RCBD) with two factors factorial. The means were compared using Duncan's multiple ranges tested at 5\% significance level.

\section{Results}

\section{Morphological characteristics}

Morphological parameters are presented in Table 1. Prominently highest values for plant height $(136 \mathrm{~cm})$ and leaf area $\left(53.7 \mathrm{~cm}^{2}\right)$ were in November under the poly tunnel conditions while in months of January $\left(47.41 \mathrm{~cm}, 15.35 \mathrm{~cm}^{2}\right)$ and February $(46.23 \mathrm{~cm}$, $\left.15.04 \mathrm{~cm}^{2}\right)$ in open filed conditions remained lowest. More number of leaves per plant (8.13), number of corms \& cormels $(34.31)$ and corm size $(3.88 \mathrm{~cm})$ was noticed in poly tunnel conditions and lower number leaf per plant (6.39), number of corms \& cormels (26.8) and corm size $(3.52 \mathrm{~cm})$ was recorded in open field conditions. Also prominently early flowering was noted in poly tunnel (71.76 day) than open field (99.74 days) while prolonged flowering was in January (91.63) and February (87.99 days).

\section{Floral and vase quality parameters}

Floral characteristics were presented in Figures 2-7. The longest spikes were noticed in November $(96.18 \mathrm{~cm})$ under poly tunnel conditions and smallest in January $(21.15 \mathrm{~cm})$ and February $(20.55 \mathrm{~cm})$ in open field conditions. The thickest diameter of spike was noted under poly tunnel in November $(12.19 \mathrm{~mm})$ while thinnest in January $(6 \mathrm{~mm})$ and February $(5.89 \mathrm{~mm})$ in open field. The highest number of florets were recorded in November (14.18) under poly tunnel while lowest in January (4.87) and February (5.16) in open field. The flower diameter was more in November $(11.22 \mathrm{~cm})$ in protected conditions while least in January $(5.3 \mathrm{~cm})$, February $(4.93 \mathrm{~cm})$ in open field. The maximum fresh weight of flower spike was in November $(9.11 \mathrm{~g})$ under poly tunnel growing conditions and minimum in January (3.67 g), February (3.8 g) in open field. The longest vase life was recorded in November (18.78 days), December (16.99 days) in poly tunnel conditions while shortest in January (9.32 days) and February (8.96 days) in open filed environment. Percentage of florets opened and days to open florets were non-significant (data not shown). 
Table 1. Effect of growing conditions and planting times on various morphological characteristics of gladiolus

\begin{tabular}{|c|c|c|c|c|c|c|c|}
\hline \multicolumn{2}{|c|}{ Treatments } & $\begin{array}{c}\text { Plant Height } \\
(\mathrm{cm})\end{array}$ & $\begin{array}{c}\begin{array}{c}\text { Number of Leaves } \\
\text { Plant }^{-1}\end{array} \\
\end{array}$ & $\begin{array}{c}\begin{array}{c}\text { Leaf Area } \\
\left(\mathrm{cm}^{3}\right)\end{array} \\
\end{array}$ & $\begin{array}{c}\text { Days Taken to } \\
\text { Flowering } \\
\end{array}$ & $\begin{array}{c}\text { No. of Corms \& Cormels } \\
\text { Plant }^{-1} \\
\end{array}$ & $\begin{array}{c}\text { Corm's Diameter } \\
(\mathrm{cm})\end{array}$ \\
\hline \multirow{4}{*}{$\begin{array}{c}\text { Growing } \\
\text { Conditions (GC) }\end{array}$} & $\begin{array}{l}\text { Open } \\
\text { Field }\end{array}$ & $63.99 \pm 4.51^{\mathrm{B}}$ & $6.39 \pm 0.58^{\mathrm{B}}$ & $23.11 \pm 1.65^{\mathrm{B}}$ & $99.74 \pm 2.07^{\mathrm{A}}$ & $26.8 \pm 2.24^{\mathrm{B}}$ & $3.52 \pm 0.18^{\mathrm{B}}$ \\
\hline & $\begin{array}{c}\text { Poly } \\
\text { Tunnel }\end{array}$ & $91.41 \pm 4.29^{\mathrm{A}}$ & $8.13 \pm 0.37^{\mathrm{A}}$ & $36.83 \pm 2^{\mathrm{A}}$ & $71.76 \pm 3.35^{\mathrm{B}}$ & $34.31 \pm 1.75^{\mathrm{A}}$ & $3.88 \pm 0.2^{\mathrm{A}}$ \\
\hline & P Value & $<0.001$ & $<0.001$ & $<0.001$ & $<0.001$ & $<0.05$ & $<0.001$ \\
\hline & LSD & 7.39 & 0.78 & 3.03 & 4.49 & 1.63 & 0.32 \\
\hline \multirow{6}{*}{$\begin{array}{l}\text { Date of Planting } \\
\text { (DP) }\end{array}$} & Nov $1^{\text {st }}$ & $113.06 \pm 4.75^{\mathrm{A}}$ & $11.11 \pm 0.8^{\mathrm{A}}$ & $43.09 \pm 1.89^{\mathrm{A}}$ & $80.49 \pm 3.46^{\mathrm{B}}$ & $36.86 \pm 2.12^{\mathrm{A}}$ & $4.2 \pm 0.11^{\mathrm{A}}$ \\
\hline & $\operatorname{Dec} 1^{\text {st }}$ & $88.84 \pm 4.72^{\mathrm{B}}$ & $9.19 \pm 0.34^{\mathrm{B}}$ & $37.75 \pm 2.06^{\mathrm{B}}$ & $82.89 \pm 2.29^{\mathrm{AB}}$ & $35.17 \pm 2.36^{\mathrm{A}}$ & $3.84 \pm 0.29^{\mathrm{AB}}$ \\
\hline & $\operatorname{Jan} 1^{\text {st }}$ & $56.14 \pm 3.26^{\mathrm{C}}$ & $4.44 \pm 0.35^{\mathrm{C}}$ & $19.47 \pm 1.43^{C}$ & $91.63 \pm 3.01^{\mathrm{A}}$ & $24.75 \pm 1.49^{\mathrm{B}}$ & $3.38 \pm 0.15^{\mathrm{BC}}$ \\
\hline & Feb $1^{\text {st }}$ & $52.76 \pm 4.89^{\mathrm{C}}$ & $4.31 \pm 0.42^{\mathrm{C}}$ & $19.56 \pm 1.92^{C}$ & $87.99 \pm 2.09^{\mathrm{AB}}$ & $25.45 \pm 2.01^{\mathrm{B}}$ & $3.49 \pm 0.21^{\mathrm{C}}$ \\
\hline & P Value & $<0.001$ & $<0.001$ & $<0.001$ & $<0.001$ & $<0.001$ & $<0.001$ \\
\hline & LSD & 10.45 & 1.11 & 4.29 & 6.36 & 2.31 & 0.45 \\
\hline \multirow{10}{*}{$\begin{array}{l}\text { Interaction } \\
\text { (GC X DP) }\end{array}$} & OF X Nov & $89.75 \pm 5.22^{C}$ & $10.06 \pm 0.96$ & $32.47 \pm 1.21^{\mathrm{C}}$ & $96.71 \pm 2.5$ & $32.19 \pm 2.33$ & $3.82 \pm 0.11$ \\
\hline & OF X Dec & $72.58 \pm 3.21^{\mathrm{D}}$ & $7.91 \pm 0.34$ & $29.57 \pm 1.26^{\mathrm{CD}}$ & $97.69 \pm 1.06$ & $30.52 \pm 2.56$ & $3.71 \pm 0.22$ \\
\hline & OF X Jan & $47.41 \pm 2.92^{\mathrm{E}}$ & $3.84 \pm 0.45$ & $15.35 \pm 1.8^{\mathrm{E}}$ & $103.08 \pm 2.46$ & $21.56 \pm 1.67$ & $3.27 \pm 0.19$ \\
\hline & OF X Feb & $46.23 \pm 6.68^{\mathrm{E}}$ & $3.76 \pm 0.58$ & $15.04 \pm 2.32^{\mathrm{E}}$ & $101.49 \pm 2.25$ & $22.94 \pm 2.39$ & $3.27 \pm 0.19$ \\
\hline & PT X Nov & $136.37 \pm 4.27^{\mathrm{A}}$ & $12.16 \pm 0.64$ & $53.7 \pm 2.57^{\mathrm{A}}$ & $64.27 \pm 4.41$ & $41.52 \pm 1.91$ & $4.37 \pm 0.1$ \\
\hline & PT X Dec & $105.1 \pm 6.22^{\mathrm{B}}$ & $10.46 \pm 0.34$ & $45.93 \pm 2.85^{\mathrm{B}}$ & $68.09 \pm 3.52$ & $39.82 \pm 2.15$ & $3.96 \pm 0.35$ \\
\hline & PT X Jan & $64.86 \pm 3.59^{\mathrm{D}}$ & $5.03 \pm 0.24$ & $23.59 \pm 1.05^{\mathrm{D}}$ & $80.18 \pm 3.55$ & $27.93 \pm 1.3$ & $3.49 \pm 0.11$ \\
\hline & PT X Feb & $59.29 \pm 3.09^{\mathrm{DE}}$ & $4.86 \pm 0.25$ & $24.08 \pm 1.52^{\mathrm{D}}$ & $74.49 \pm 1.93$ & $27.97 \pm 1.63$ & $3.71 \pm 0.22$ \\
\hline & P Value & $<0.05$ & $>0.05$ & $<0.01$ & $>0.05$ & $>0.05$ & $>0.05$ \\
\hline & LSD & 14.79 & 1.58 & 6.07 & 8.99 & 3.26 & 0.62 \\
\hline \multicolumn{2}{|l|}{$\mathrm{CV}$} & 5.56 & 12.42 & 11.57 & 5.99 & 10.83 & 16.77 \\
\hline
\end{tabular}

Means sharing same letters are none significant and \pm showed the standard error of three means of each replicates. Abbreviations: $(\mathrm{DP}=\mathrm{Date}$ of planting, OF $=$ Open Field, PT = Polythene Tunnel, P Value: shows the significance level, LSD = Least Significant Difference, CV = Coefficient of Variation) 

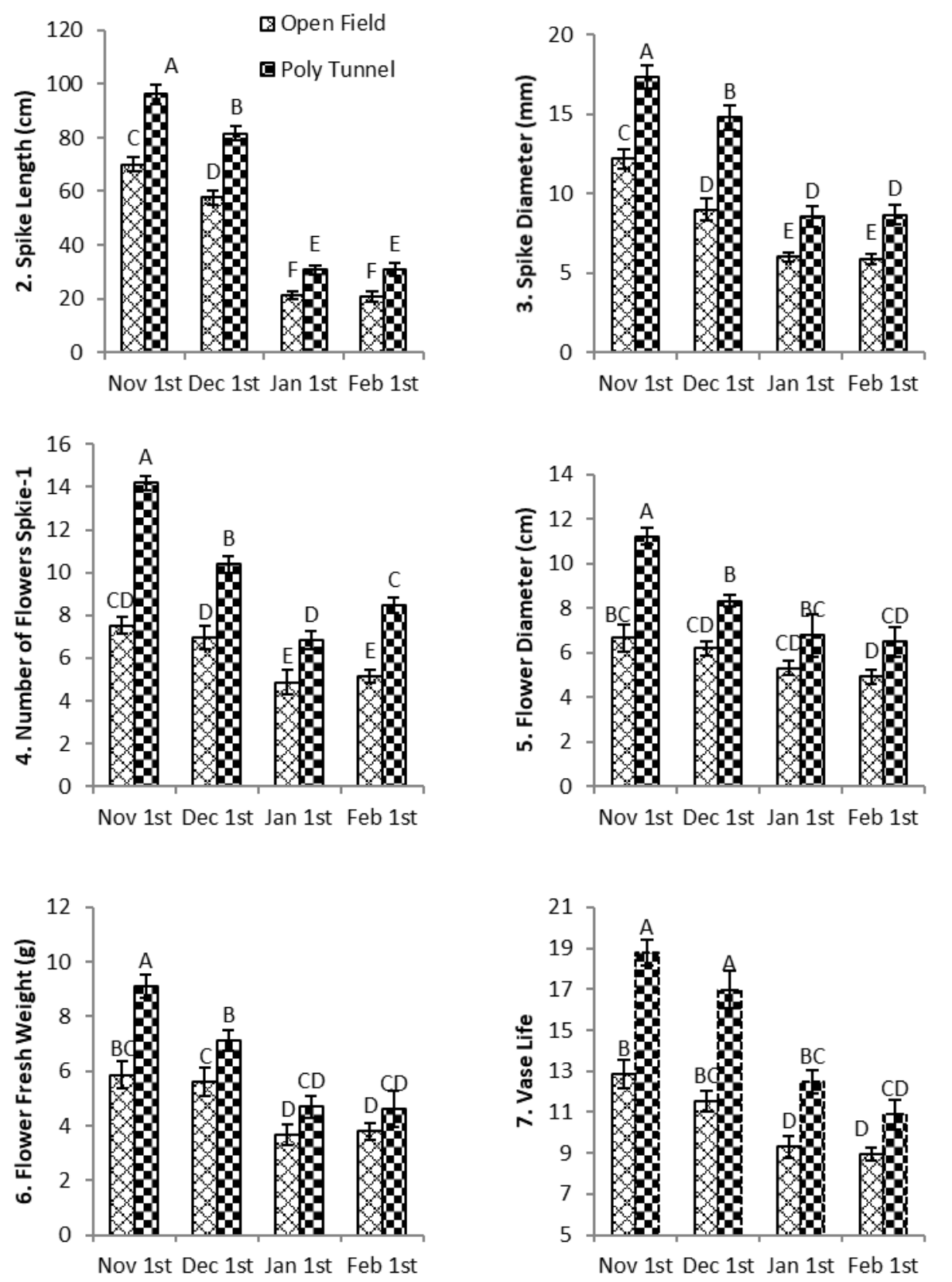

Figures 2-7. Effect of growing conditions and planting time on floral attributes (Bar shows standard error of means)

\section{Bio-chemical and physiological characteristics}

Bio-chemical and physiological characteristics are shown in Figures 8-12. The chlorophyll (SPAD) contents were highest in November (79.20, 68.45) and minimum in January $(49.44,43.15)$. Photosynthetic rate was more during November $\left(3.32 \mathrm{~mol} \mathrm{~m}^{-2} \mathrm{~s}^{-1}\right.$, $\left.2.85 \mathrm{~mol} \mathrm{~m}^{-2} \mathrm{~s}^{-1}\right)$ in both conditions while minimum during January $\left(1.52 \mathrm{~mol} \mathrm{~m}^{-2} \mathrm{~s}^{-1}\right)$ and February $\left(1.56 \mathrm{~mol} \mathrm{~m}^{-2} \mathrm{~s}^{-1}\right)$ in open field conditions. The highest transpiration rate was noticed during November $\left(1.39 \mathrm{~mol} \mathrm{~m}^{-2} \mathrm{~s}^{-1}, 1.29 \mathrm{~mol} \mathrm{~m}^{-2} \mathrm{~s}^{-1}\right)$ while minimum during February $\left(0.9 \mathrm{~mol} \mathrm{~m}^{-2} \mathrm{~s}^{-1}\right)$ in both conditions, respectively. The maximum relative water 
contents were recorded in November $(90.33 \%)$ under poly tunnel while lowest in January $(78.44 \%)$ in open field. Stomatal conductance was more November $(0.0064$, $\left.0.0068 \mathrm{~mol} \mathrm{~m}^{-2} \mathrm{~s}^{-1}\right)$ and least in February $\left(0.0046,0.0053 \mathrm{~mol} \mathrm{~m}^{-2} \mathrm{~s}^{-1}\right)$ in both conditions, respectively.
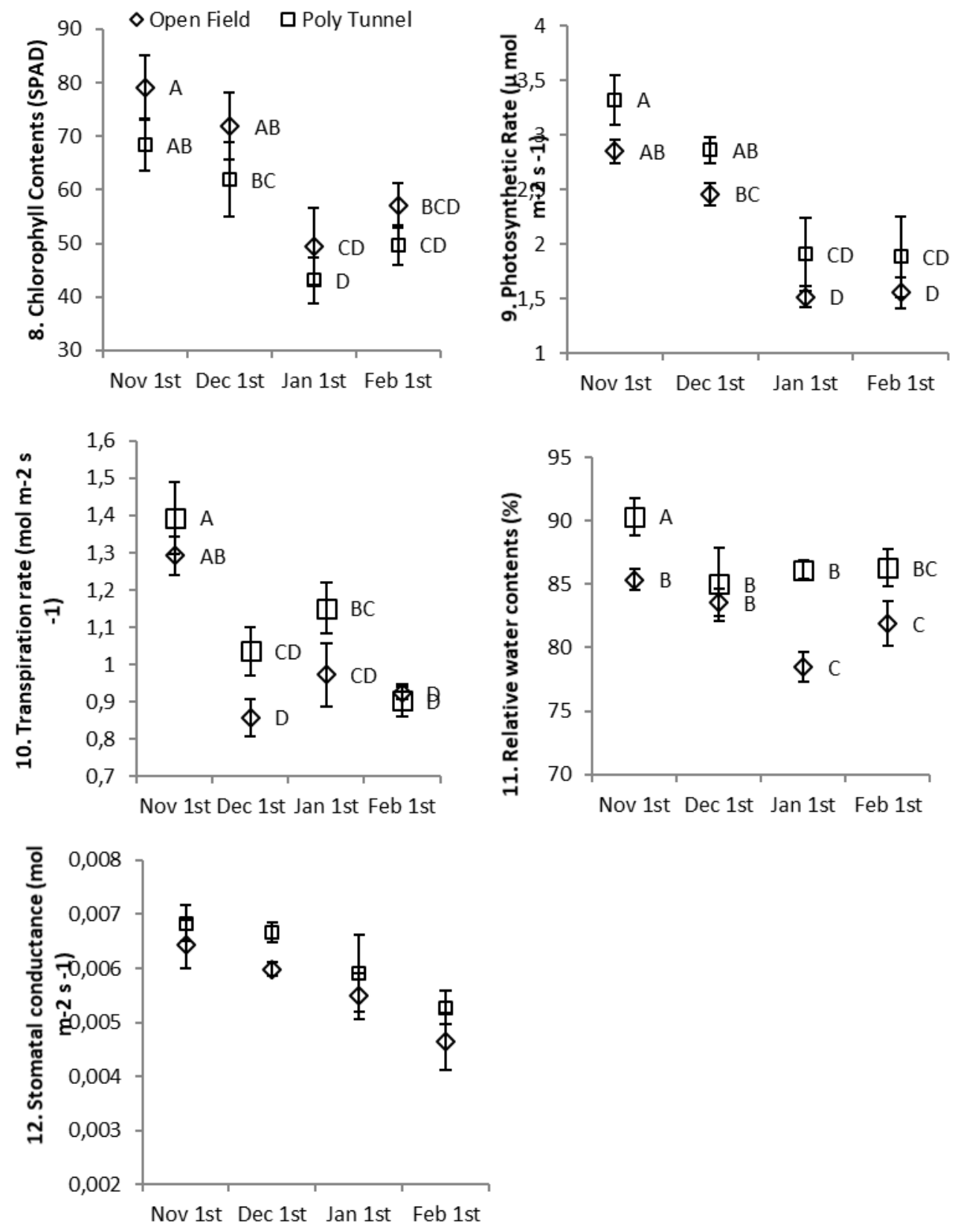

Figures 8-12. Effect of growing conditions and planting time on biochemical and physiological features (Bar shows standard error of means)

\section{Antioxidant enzyme activity and membrane leakage}

Antioxidant enzyme activities (POD \& CAT) and electrolyte leakage are given in Figures 13-15. The maximum peroxidase activity in gladiolus cut flower were recorded 
in gladiolus spikes grown in November (57.85 $\mathrm{U} \mathrm{g}^{-1}$ fresh weight) and December (53.60 $\mathrm{U} \mathrm{g}^{-1}$ fresh weight) under poly tunnel conditions at day 6 stage throughout the vase period while least during January $\left(20.83 \mathrm{U} \mathrm{g}^{-1}\right.$ fresh weight) and February (21.62 $\mathrm{U} \mathrm{g}^{-1}$ fresh weight) at harvest day in open field conditions. The maximum catalase activity in gladiolus cut flower were recorded in gladiolus spikes grown under the polythene tunnel planting in the month of November $\left(12.83 \mathrm{U} \mathrm{g}^{-1}\right.$ fresh weight) and December (12.31 $\mathrm{U} \mathrm{g}^{-1}$ fresh weight) at day 6 while the least during January (3.25 $\mathrm{U} \mathrm{g}^{-1}$ fresh weight) and February (2.75 $\mathrm{U} \mathrm{g}^{-1}$ fresh weight) at harvest day in open field condition. The maximum electrolyte leakage was recorded in gladiolus spikes grown under the open field in the month of January (45.36\%), February $(44.6 \%)$ while minimum in November $(25.28 \%)$ and December $(26.43 \%)$.
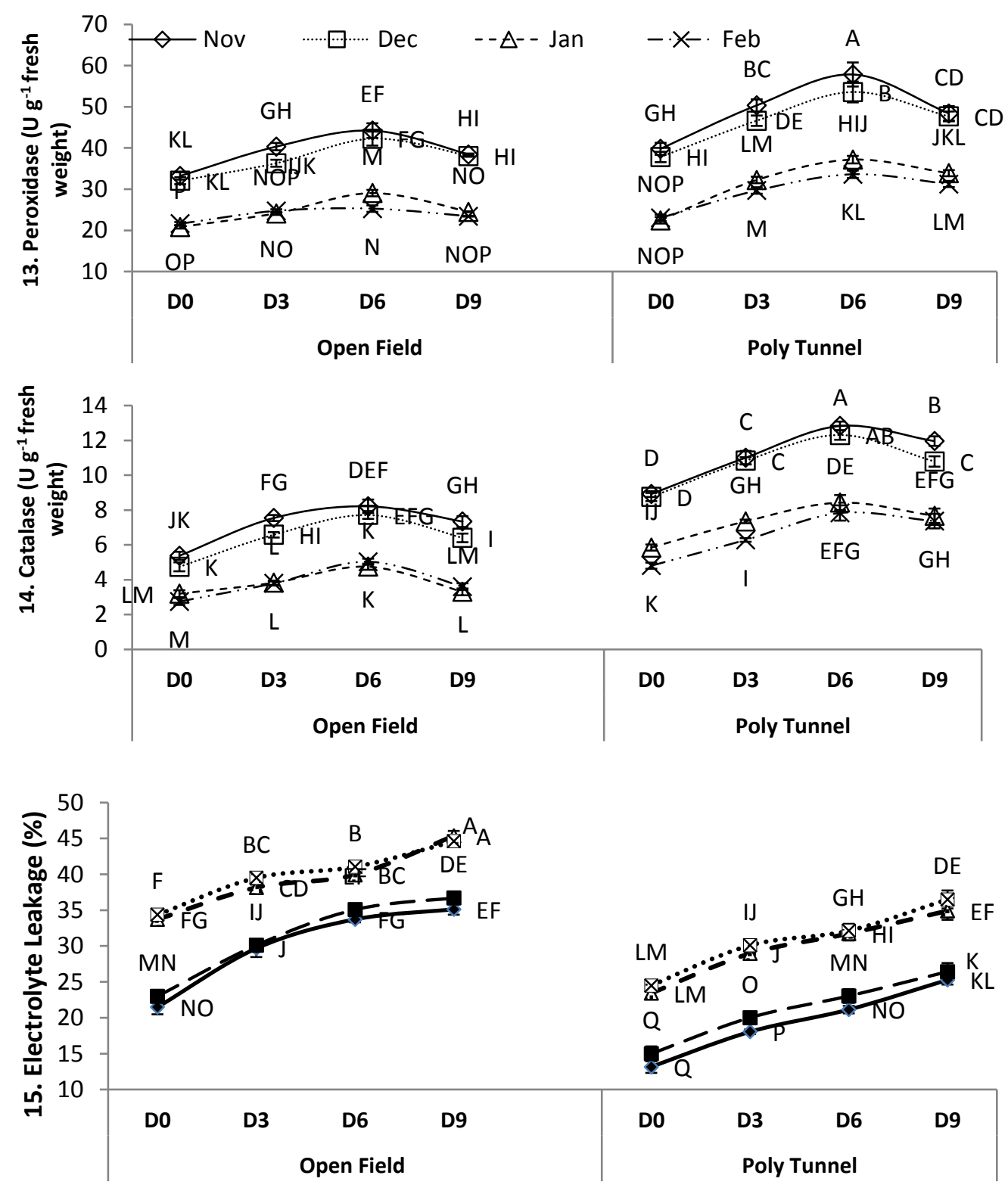

Figures 13-15. Effect of growing conditions and planting time on antioxidant activities (POD, $C A T)$ and electrolyte leakage (Bar shows standard error of means) 


\section{Correlation of characteristics with temperature}

Correlation of various studied characteristic with growing temperature is presented in Figure 16. The most of the correlation coefficient values (r) for morphological, physiological and antioxidant activities showed a stronger positive relation with average temperature in respective growing condition. The temperature ranges from $13-25^{\circ} \mathrm{C}$. As temperature decrease the growth of the gladiolus also decreases. However, correlation coefficient values showed that days taken to flowering and days to open florets prolonged as temperature decreased. Also electrolyte leakage increased with the decreasing of temperature.

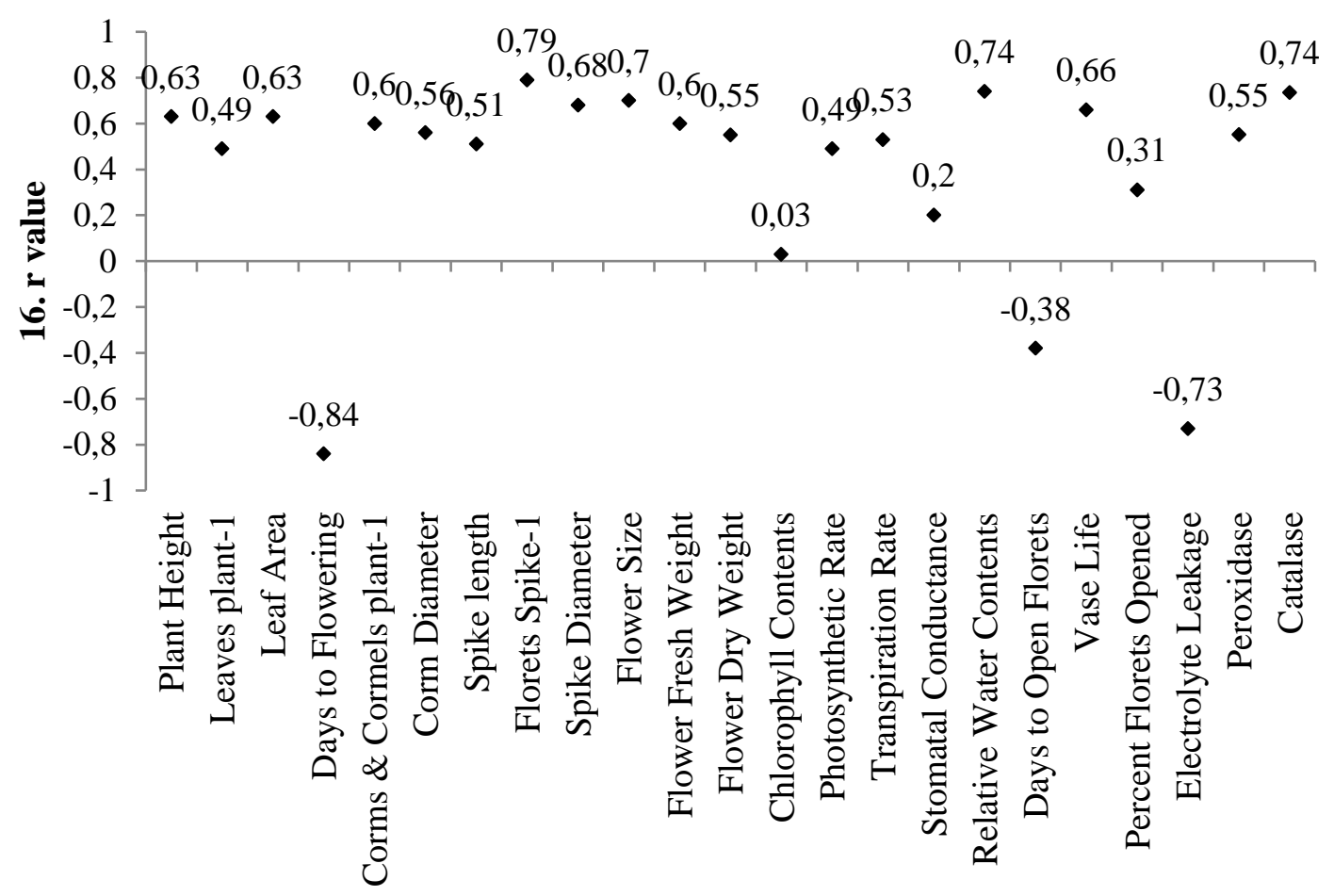

Figure 16. Correlation coefficient ( $r$ ) with temperature of studied characteristics

\section{Discussion}

\section{Morphological, floral and vase life attributes}

Morphological, floral and vase life attributes significantly affected by temperature. The temperature is a principal feature influencing the plant growth rate and development. Optimum temperature enhanced the growth of plants positively (Khodorova and BoitelConti, 2013; Hatfield and Prueger, 2015). The growth of vegetative parts enhances as temperature increased to optimum level of the species (Paustian et al., 2004; Hatfield et al., 2011; Abbas et al., 2017). Temperature may influence the cell division and cell enlargement because all metabolic processes need a certain temperature and all enzymes functions at a specific temperature generally higher than freezing temperature. The polythene tunnel system enhances the temperature of the microclimate which favors the plants internal enzymes and photosynthates ultimately increasing leaf number per plant. As observed in gerbera cut flower produced under protected conditions (Soni and Godara, 2017). The temperature and relative humidity regulate the transpiration rate that involved 
in nutrients and water uptake from root to leaves and thus higher rate of nutrients accumulation positively influenced the leaf size (Jezek et al., 2015). The cold temperature, by distressing the carbonic anhydrase activity lessens net photosynthesis in plants. Carbonic anhydrase is a restrictive enzyme for $\mathrm{CO}_{2}$. The decrease fresh weight due to low temperature might be ascribed to the lower carbonic anhydrase activity or impaired protein synthesis that limited the growth (Franklin, 2009). Also, short days in later month with low temperature reduced the photosynthetic activity, due to which carbohydrate accumulation and the diameter of spikes ultimately reduced (Klein et al., 2007; Sacks and Kucharik, 2011). The temperature below freezing point during winter season reduces growth and energy storage of plants. Plants are prepared better to resist cold temperature when they are sheltered from severe circumstances (Ali et al., 2016). The low temperature during later months of January and February may reduce assimilates which can be insufficient to maintain flower meristem differentiation and cessation of cell division due to which carbohydrate accumulation reduced that eventually lower floral quality (Streck, 2004; Klein et al., 2007; Sacks and Kucharik, 2011). Low temperature damages several enzymes, their functional and structural component, such as alcohol dehydrogenase, phospholipase, carbonic anhydrase, alkaline phosphatase, RNA polymerase and carboxypeptidase which reduced fresh and dry weight (Mohanty et al., 2011). Alike results were reported on increased dry matter production in favorable temperature under protected production conditions in roses (Ahmad et al., 2011).

The application of protective polythene tunnel increased the inside temperature that promoted the translocation of photosynthates from the source to sink which favors growth attributes (Barthel et al., 2014; Schwab et al., 2015). Also the favorable temperature might enhance the carbohydrates and sugar translocation by formation of B-polyol complex (sugars alcohols binding with boric acid). Thus, enhanced its accumulation within plant, caused to form the more floral primordia in the shoot apical meristem resulted in higher number of florets per spike (Usha et al., 2002). The greater area of a leaf give assurance that higher chlorophyll contents will be present and leaf absorb more photosynthetically active radiations (PAR). Hence, both these aspects regulate higher rate of photosynthesis which enhanced accumulation of carbohydrates for growth and development (Sage and Kubien, 2007; Ahmad et al., 2011). The temperature up to favorable range with higher day length incriminate in the uptake and translocation of nutrients inside plant which leads to increase in underground parts production of plant (Joshi et al., 2011). Furthermore, higher area of leaves and more photosynthates in the particular month inside protected polythene tunnel treatment might be supportive in enhancing the corms and cormels number per plant and size of corms (Laishram et al., 2011; Mahesh and Moond, 2011).

The temperature inside the protected structure rose due to the blocking of infrared radiations (Lim et al., 2017). Temperature influence the time taken to flowering significantly. During early stages at which floret differentiation occur was most sensitive to temperatures and light intensities. Photoperiods and temperature influenced the time taken to flowering and flower development (Motomura et al., 2002; Sudhakar and Kumar, 2015). At warmer temperatures plants attain more carbohydrates for growth and development which ultimately helped plants to take lesser time to flowering (Shillo et al., 1981). Similar result of earlier maturity under protected structures in comparison to open field in tomato was reported by Parvej et al. (2010).

Senescence is the ultimate phase of flower life, which results in drooping of whole flower or the floral parts. The genetically controlled programmed known as senescence 
in flower petals is directly triggered on the opening of floral bud. This process is not reversible in floral tissues (van Doorn and Woltering, 2004; Kumar et al., 2008). Overall growth of spikes is responsible for the opening of florets. Pre harvest growth designates the ultimate postharvest life of the flower spike (Gupta and Dubey, 2018). Vase life can be affected by transpiration, respiration, reactive oxygen species, and membrane leakage (Ezhilmathi et al., 2007). Preharvest morphological and physiological parameters at harvest were relevant to a considerable extent in vase life. Water uptake from the vase solution is attributed to better water balance, flower freshness and fresh weight and prevents the cut flower from early wilting (Ataii et al., 2015). The pre harvest accumulation of carbohydrates plays significant role in postharvest life of the cut flowers. These carbohydrates maintain osmotic potential within plants, which results in improved water uptake in cut spike. Thus better growth is maintained in pre harvest life and provides cut flowers with a better opportunity to perform in shelf life period (Da Silva, 2006). Healthier spike in respect to diameter, fresh weight, and floret size ensures the longer vase life (Slootweg et al., 1999). In the current studies the vase life was positively correlated with these morphological and physiological parameters.

\section{Biochemical and physiological parameters}

Chlorophyll contents were higher in plants those grown in earlier planting times when the temperature and long days having more light availability. More chlorophyll contents were notice in open field as compared to protected field conditions might be due to more availability of photo active radiations (Mohanty et al., 2006). These findings confirmed the findings of Ahmad and Usman (2013) and Qasim et al. (2008) who noticed more chlorophyll contents in open field production of rose. The relative water contents (RWC) might differ significantly with changing temperature in fast growing tissues, irrespective of the any growth stage. However, measurement of RWC remains very small because of limited potential for expansion of cells. Low cell metabolism rates in more mature and slow-growing leaves (Shinozaki et al., 2003; Kaplan et al., 2004).

The light-dependent photosynthetic reactions are not influenced by modifications in temperature. However, the photosynthetic light independent reactions are significantly affected by changes in temperature. There were various enzymes that catalysed these reactions. The rate of catalysis of these enzymes was increased as their temperatures attained at optimum levels. The rate starts to decline at low temperature, as enzymes became denatured (Schwender et al., 2004). The plant exposure to low temperature stress contributes to metabolism alterations in two ways. Formerly, because of increasing or decreasing the temperature, plants try to regulate the cellular metabolism. Secondly, structural changes, catalytic properties, enzyme functions and membrane metabolite transporters alter due to temperature stress. The enzymes that carry out photosynthesis do not work efficiently at low temperatures between 0 and 10 , and this decreases the photosynthetic rate (Kubien et al., 2003; Fernie et al., 2005).

Temperature stress alone or in combination with $\mathrm{CO}_{2}$ fluctuation alters the stomatal conductance in plants. Particularly in the leaf petiole reduction of both stomatal conductance and mesophyll conductance about 10-30\% occurs only within 10 minutes of lower temperature. Likewise, major responses of stomatal conductance within 20-30 min took place due to variations in leaf temperature in plants acclimated together to low temperature (Gorton et al., 2003; Warren and Dreyer, 2006). The similar response of both mesophyll and stomatal variations in almost all environmental variables signifies that stomatal conductance co-regulated in order to availability of favorable temperature. 
These findings favour the current study that in protected conditions and early month of plantations the temperature was favorable, due to which the stomatal conductance was better (Kerstiens, 2006; Morison and Lawson, 2007).

The temperature significantly affects the magnitude of the driving force to move water out of a plant instead of directly affecting stomata. The water holding capability of air rises abruptly as temperature rises. The warmer air can hold more water as compared to cooler air. Therefore, the driving force for transpiration rise in warmer air and reduced in the cooler air (Thakur et al., 2010; Mantri et al., 2012; Bala and Singh, 2013). The photosynthetic activity was good due to better stomatal conductance and transpiration which ultimately favors the growth and floral quality of gladiolus plants in protected conditions.

\section{Antioxidant enzyme activity and membrane leakage attributes}

The preeminent antioxidant enzymes (POD, CAT) activity was noticed in experiment during the early month November and December plantations. It might be characterized to strong activity antioxidative enzymes during favorable temperature conditions. However, during severe low temperature conditions in January and February, the antioxidant activities were remained lower in gladiolus cut flowers. Various toxic reactive oxygen species are generated due to stress. $\mathrm{H}_{2} \mathrm{O}_{2}$ is one the most abundantly produced radical, which in excess could harm the cell. The antioxidants enzymes peroxidase (POD) and catalase (CAT) are responsible for the biological removal of $\mathrm{H}_{2} \mathrm{O}_{2}$ from the cell (Mei and Song, 2008; Akhtar et al., 2010). These enzymes are produced in plant tissues according to their defence system during growth stages progression which specifies the defence mechanism in the shelf life of cut flower. The ROS is possibly generated due to low temperature stress (Hasegawa et al., 2000; Guo et al., 2016). The activities of antioxidative enzymes are reduced in extreme coldness beyond the plant's tolerant level or in chilling sensitive plants due to that ROS accumulated in greater extent (Solanke and Sharma, 2008; Chen and Arora, 2011). These higher amounts of ROS imposed the stress. The lipid, protein, carbohydrate and DNA damaged by this stress ultimately effecting physiological processes (Gill and Tuteja, 2010), thus causes cell death and adversely affect plants (Apel and Hirt, 2004). The excessive amount of $\mathrm{H}_{2} \mathrm{O}_{2}$ accumulation would be toxic to plants tissue in plant exposed to the abiotic stress (Zheng et al., 2009). It could be the reason that excess $\mathrm{H}_{2} \mathrm{O}_{2}$ imposed due to lower temperature stress resulted lower POD and CAT activity and short vase life in gladiolus cut flowers. Optimum temperature supply might be resulted in $\mathrm{H}_{2} \mathrm{O}_{2}$ release, thus enhanced POD and CAT level and extended vase life was noted (Nahar et al., 2009).

Electrolyte leakage was higher in plants grown in low temperature months at open field environment. The leakage of electrolyte in intact plant cells is a characteristic of stress response. This phenomenon is commonly used as a measure of plant stress tolerance (Bajji et al., 2004; Lee and Zhu, 2010). The membrane structure of tissues in plants was damaged under stress induced by low temperature. The intracellular leakage rate of electrolyte induced by cold stress reflected the amount of cell membrane damage. The plant response aptitude to cold stress is efficiently assessed indirectly by the relative conductance value. With the continuity of low temperature stress, the degree of damage was aggravated in cellular membrane (Liu et al., 2013). Increase in electrolyte leakage due to low temperature stress also observed in wheat (Chen et al., 2006), coffee seedlings (Azzarello et al., 2009) and tomato (Ghiasi and Razavi, 2013). 


\section{Conclusion}

Gladiolus grown in two different growing environments revealed significant variations in morpho-physiological characteristics from November until February. Climate variables had a significant impact on growth and development of gladiolus. In early planting during November and December under polythene tunnel has positive effects on growth, production and floral characteristics of gladiolus cut flowers. The quality and vase life of cut flowers improved as biochemical characteristics, antioxidative enzymes activities enhanced and membrane remained stable. The application of polythene sheet during November and December months render the best results for improving growth and quality of gladiolus cut flowers. The polythene sheet significantly lower the stress imposed by low temperature. Moreover, mitigation with polythene sheet during January and February gives significant improvement in the growth and vase life attributes of gladiolus. However, lowest morpho-physiological indices of gladiolus were observed in January and February. Positive correlation of temperature was observed regarding growth and development of gladiolus. Such observations and previous literature findings indicate that more research is needed to measure the interactions between temperature and plant hardiness of gladiolus across germplasm within a species and between species to evaluate possible adaptation strategies to mitigate the negative effects of extreme temperature events.

Acknowledgements. The authors gratefully acknowledge the support of my beloved father "MUHAMMAD ABDUL QAYYUM AZIZ, Chief Engineer WAPDA Pakistan" for studies and throughout my career. The results presented here are part of $\mathrm{PhD}$ research of principal author. The authors acknowledge my Supervisor "Dr. Imran Hassan, Associate Professor" for providing the guidance and moral support. The authors also appreciate Plant Physiology \& Central Laboratory, PMAS, Arid Agriculture University, Rawalpindi, Pakistan for provision of facilities and instruments.

\section{REFERENCES}

[1] Abbas, Z. K., Saggu, S., Rehman, H., Al Thbiani, A., Ansari, A. A. (2017): Ecological variations and role of heat shock protein in Artemisia judaica L. in response to temperature regimes of Tabuk, Saudi Arabia. - Saudi Journal of Biological Science 24: 1268-1273.

[2] Abbasi, N. A., Kushad, M. M., Endress, A. G. (1998): Active oxygen-scavenging enzymes activities in developing apple flowers and fruits. - Scientia Horticulturea 74: 183-194.

[3] Ahmad, I., Khalid, M. S., Khan, M. A., Saleem, M. (2011): Morpho-physiological comparison of cut rose cultivars grown in two production systems. - Pakistan Journal of Boanyt 43: 2885-2890.

[4] Ahmad, I., Usman, S. R. (2013): Humic acid and cultivar effects on growth, yield, vase life, and corm characteristics of gladiolus. - Chilean Journal of Agricultural Research 73: 339-344.

[5] Ahmad, M., Rab, A. (2020): Calcium effects on post-harvest attributes and vase life of gladiolus using different methods of application. - Pakistan Journal of Botany 52(1): 167179.

[6] Akhtar, A., Abbasi, N. A., Hussain, A. (2010): Effect of calcium chloride treatments on quality characteristics of loquat fruit during storage. - Pakistan Journal of Botany 42: 181188.

[7] Ali, Z., Shabbir, M., Qadeer, A., Ahmad, H., Qasim, M., Aziz, O. (2016): Performance evaluation of Gladiolus varieties under diverse climatic conditions. - Plant Gene \& Trait 7(4): $1-9$. 
[8] Anderson, N. O., Frick, J., Younis, A., Currey, C. (2012): Heritability of cold tolerance (winter hardiness) in Gladiolus $\times$ grandiflorus. - In: Abdurakhmonov, I. Y. (ed.) Plant Breeding, InTech, chapter 13: 297-331.

[9] Apel, K., Hirt, H. (2004): Reactive oxygen species: metabolism, oxidative stress, and signal transduction. - Annual Review of Plant Biology 55: 373-399.

[10] Arora, J. S. (2007): Introductory Ornamental Horticulture. - Kalyani publishers, New Delhi, India: 61-67.

[11] Ataii, D., Naderi, R., Khandan-Mirkohi, A. (2015): Delaying of postharvest senescence of lisianthus cut flowers by salicylic acid treatment. - Journal of Ornamental Plants 5: 67-74.

[12] Azzarello, E., Mugnai, S., Pandolfi, C., Masi, E., Marone, E., Mancuso, S. (2009): Comparing image (fractal analysis) and electrochemical (impedance spectroscopy and electrolyte leakage) techniques for the assessment of the freezing tolerance in olive. - Trees 23: 159.

[13] Bajji, M., Bertin, P., Lutts, S., Kinet, J. (2004): Evaluation of drought resistance-related traits in durum wheat somaclonal lines selected in vitro. - Australian Journal of Experimental Agriculture 44: 27-35.

[14] Bala, M., Singh, K. (2013): Effect of different potting media for pot mum production in chrysanthemum grown under open and polyhouse conditions. - Journal of Ornamental Horticulture 16: 35-39.

[15] Bars, H. D., Weatherley, P. E. (1962): A re-examination of relative turgidity technique for estimating water deficit in leaves. - Australian Journal of Biological Science 15: 413-428.

[16] Barthel, M., Cieraad, E., Zakharova, A., Hunt, J. (2014): Sudden cold temperature delays plant carbon transport and shifts allocation from growth to respiratory demand. Biogeosciences 11: 1425-1433.

[17] Bhande, M. H., Neha, C., Sushma, L., Parinita, W. (2015): Effect of spacing and corm size on growth, yield and quality of gladiolus. - Plant Archives 15(1): 541-544.

[18] Chen, Y., Zhang, M., Chen, T., Zhang, Y., An, L. (2006): The relationship between seasonal changes in anti-oxidative system and freezing tolerance in the leaves of evergreen woody plants of Sabina. - South African Journal of Botany 72: 272-279.

[19] Chen, K., Arora, R. (2011): Dynamics of the antioxidant system during seed osmopriming, post-priming germination, and seedling establishment in Spinach (Spinacia oleracea). Plant Science 180: 212-220.

[20] Cowan, J. S., Miles, C. A., Andrews, P. K., Inglis, D. A. (2014): Biodegradable mulch performed comparably to polyethylene in high tunnel tomato (Solanum lycopersicum L.) production. - Journal of the Science of Food and Agriculture 94(9): 1854-1864.

[21] Da Silva, J. A. T. (2006): Ornamental cut flowers: physiology in practice. - In: Floriculture, Ornamental and Plant Biotechnology: Advances and Tropical Issues, pp. 124-140.

[22] Ezhilmathi, K., Singh, V., Arora, A., Sairam, R. (2007): Effect of 5-sulfosalicylic acid on antioxidant activity in relation to vase life of Gladiolus cut flowers. - Plant Growth Regulation: 51(2): 99-108.

[23] Fernie, A. R., Geigenberger, P., Stitt, M. (2005): Flux an important, but neglected, component of functional genomics. - Current Opinion on Plant Biology 8: 174-182.

[24] Franklin, K. A. (2009): Light and temperature signal crosstalk in plant development. Current Opoinion on Plant Biology 12: 63-68.

[25] Ghiasi, N., Razavi, F. (2013): Impact of postharvest prohexadione calcium treatment on PAL activity in tomato fruit in response to chilling stress. - Iranian Journal of Plant Physiology 4(1): 865-871.

[26] Gill, S. S., Tuteja, N. (2010): Reactive oxygen species and antioxidant machinery in abiotic stress tolerance in crop plants. - Plant Physiology \& Biology 48: 909-930.

[27] Gorton, H. L., Herbert, S. K., Vogelmann, T. C. (2003): Photoacoustic analysis indicates that chloroplast movement does not alter liquid-phase $\mathrm{CO}_{2}$ diffusion in leaves of Alocasia brisbanensis. - Plant Physiology 132: 1529-1539. 
[28] Guo, W., Nazim, H., Liang, Z., Yang, D. (2016): Magnesium deficiency in plants: an urgent problem. - The Crop Journal 4: 83-91.

[29] Gupta, J., Dubey, R. (2018): Factors Affecting Post-Harvest Life of Flower Crops. International Journal of Current Microbiology and Applied Sciences 7: 548-557.

[30] Hanan, J. J. (2017): Greenhouses: advanced technology for protected horticulture. - CRC press, p.684.

[31] Hasegawa, P. M., Bressan, R. A., Zhu, J. K., Bohnert, H. J. (2000): Plant cellular and molecular responses to high salinity. - Annual Reviewof Plant Biology 51: 463-499.

[32] Hatfield, J. L., Boote, K. J., Kimball, B. A., Ziska, L. H., Izaurralde, R. C., Ort, D., Wolfe, D. (2011): Climate impacts on agriculture: implications for crop production. - Agronomy Journal 103(2): 351-370.

[33] Hatfield, J. L., Prueger, J. H. (2015): Temperature extremes: Effect on plant growth and development. - Weather and Climate Extremes 10: 4-10.

[34] Jezek, M., Geilfus, C.-M., Bayer, A., Mühling, K. H. (2015): Photosynthetic capacity, nutrient status, and growth of maize (Zea mays L.) upon MgSO4 leaf-application. Frontiers in Plant Science 5: 781.

[35] Jiang, X. B. (2011): Physiological and biochemical responses to low temperature stress in hybrid clones of Populus ussuriensis Kom. $\times$ P. deltoides Bartr. - African Journal of Biotechnology 10(82): 58-97.

[36] Joshi, K., Gautam, D., Baral, D., Pun, U. (2011): Effect of corm size and varieties on corm/cormels production and vase life of gladiolus. - Nepal Journal of Science and Technology 12: 35-40.

[37] Kaplan, F., Kopka, J., Haskell, D. W., Zhao, W., Schiller, K. C., Gatzke, N., Sung, D. Y., Guy, C. L. (2004): Exploring the temperature-stress metabolome of Arabidopsis. - Plant Physiology 136: 4159-4168.

[38] Kerstiens, G. (2006): Water transport in plant cuticles: an update. - Journal of Experimental Botany 57: 2493-2499.

[39] Khodorova, N. V., Boitel-Conti, M. (2013): The Role of Temperature in the Growth and Flowering of Geophytes. - Plants (Basel) 2(4): 699-711.

[40] Klein, J. A., Harte, J., Zhao, X. Q. (2007): Experimental warming, not grazing, decreases rangeland quality on the Tibetan Plateau. - Ecological Application 17: 541-557.

[41] Kubien, D. S., von Caemmerer, S., Furbank, R. T., Sage, R. F. (2003): C4 photosynthesis at low temperature. A study using transgenic plants with reduced amounts of Rubisco. Plant Physiology 132: 1577-1585.

[42] Kumar, N., Srivastava, G. C., Dixit, K. (2008): Role of sucrose synthase and invertases during petal senescence in rose (Rosa hybrida L.). - The Journal of Hortcultural Science \& Biotechnology 83: 520-524.

[43] Laishram, N., Singh, A., Hatibarua, P. (2011): Division of corms for increasing planting material of gladiolus: Cut corm segments of gladiolus increases number of propagules. Lambert Academic Publishing, pp. 25-46.

[44] Lee, B. H., Zhu, J. K. (2010): Phenotypic analysis of Arabidopsis mutants: electrolyte leakage after freezing stress. - Cold Spring Harbor Protocols: 49-70.

[45] Lim, J. H., Choi, H. W., Ha, S. T., In, B. C. (2017): Greenhouse dehumidification extends postharvest longevity of cut roses in winter season. - Korean Journal of Horticultural Science \& Technology 35: 737-746.

[46] Liu, W., Yu, K., He, T., Li, F., Zhang, D., Liu, J. (2013): The low temperature induced physiological responses of Avena nuda L., a cold-tolerant plant species. - The Scientific World Journal 17(4): 113-119.

[47] Long, S. P., Bernacchi, C. J. (2003): Gas exchange measurements, what can they tell us about the underlying limitation to photosynthesis procedures and sources of error. - Journal of Experimental Botany 54: 2393-2401.

[48] Mahesh, C., Moond, S. A. K. (2011): Correlation studies in gladiolus. - Research in Plant Biology 1: 68-72. 
[49] Mantri, N., Patade, V., Penna, S., Ford, R., Pang, E. (2012): Abiotic stress responses in plants: present and future. - In: Ahmad, P., Prasad, M. N. V. (eds.) Abiotic stress responses in plants. Chapter 1: 1-19.

[50] Mayoli, R. N., Isutsa, D. K. (2012): Relationships of light intensity and temperature with growth and development of preconditioned and shaded ranunculus plants under high altitude tropical conditions. - International Journal of Advanced Biological Research 2(1): 24-29.

[51] Mei, Y., Song, S. (2008): Cross-tolerance is associated with temperature and salinity stress during germination of barley seeds. - Seed Science and Technology 36: 689-698.

[52] Mohanty, S., Grimm, B., Tripathy, B. C. (2006): Light and dark modulation of chlorophyll biosynthetic genes in response to temperature. - Planta 224: 692-699.

[53] Mohanty, C., Mohanty, A., Das, A., Kar, D. (2011): Comparative performance of some rose varieties under open and protected environment. - Asian Journal of Horticulture 6: 288-293.

[54] Morison, J. I., Lawson, T. (2007): Does lateral gas diffusion in leaves matter? - Plant Cell \& Environment 30: 1072-1085.

[55] Motomura, S., Doi, M., Inamoto, K., Imanishi, H. (2002): Postharvest factors affecting the vase life of cut roses. - Journal of Japanease Society of Horticulture Science 71: 415.

[56] Nahar, K., Biswas, J., Shamsuzzaman, A., Hasanuzzaman, M., Barman, H. (2009): Screening of indica rice (Oryza sativa L.) genotypes against low temperature stress. Botany Research International 2: 295-303.

[57] Parvej, M., Khan, M., Awal, M. (2010): Phenological development and production potentials of tomato under polyhouse climate. - Journal of Agriculture Science 5(1): 1931.

[58] Paustian, K., Babcock, B., Hatfield, J., Kling, C., Lal, R., McCarl, B., Mclaughlin, S., Mosier, A., Post, W., Rice, C. (2004): Climate change and greenhouse gas mitigation: challenges and opportunities for agriculture. - CAST Task Force Report: 141.

[59] Porter, J. R. (2005): Rising temperatures are likely to reduce crop yields. - Nature 436(7048): 174.

[60] Qasim, M., Ahmad, I., Ahmad, T. (2008): Optimizing fertigation frequency for Rosa hybrida L. - Pakistan Journal of Botany 40: 533-545.

[61] Sacks, W. J., Kucharik, C. J. (2011): Crop management and phenology trends in the US Corn Belt: Impacts on yields, evapotranspiration and energy balance. - Agricultural and Forest Meteorology 151: 882-894.

[62] Saeed, T., Hassan, I., Jilani, G., Abbasi, N. A. (2013): Zinc augments the growth and floral attributes of gladiolus, and alleviates oxidative stress in cut flowers. - Scientia Horticulturea 164: 124-129.

[63] Sage, R. F., Kubien, D. S. (2007): The temperature response of C3 and C4 photosynthesis. - Plant, Cell and Environment 30: 1086-1106.

[64] Sanghera, G. S., Wani, S. H., Hussain, W., Singh, N. (2011): Engineering cold stress tolerance in crop plants. - Current Genomics 12(1): 30-43.

[65] Schwab, N. T., Streck, N. A., Becker, C. C., Langner, J. A., Uhlmann, L. O., Ribeiro, B. S. M. R. (2015): A phenological scale for the development of Gladiolus. - Annual of Applied Biology 166: 496-507.

[66] Schwender, J., Ohlrogge, J., Shachar-Hill, Y. (2004): Understanding flux in plant metabolic networks. - Current Opinion on Plant Biology 7: 309-317.

[67] Shillo, R., Valis, G., Halevy, A. H. (1981): Promotion of flowering by photoperiodic lighting in winter-grown gladiolus planted at high densities. - Scientia Horticulturea 14: 367-375.

[68] Shinozaki, K., Yamaguchi-Shinozaki, K., Seki, M. (2003): Regulatory network of gene expression in the drought and cold stress responses. - Current Opinion on Plant Biology 6: 410-417. 
[69] Singh, A., Kumar, J., Kumar, P. (2008): Effect of plant growth regulators and sucrose on postharvest physiology, membrane stability and vase life of cut spikes of gladiolus. - Plant Growth Regulation 55: 221-229.

[70] Slootweg, G., Ten Hoope, M., De Gelder, A. (1999): Seasonal changes in vase life, transpiration and leaf drying of cut roses. - VII International Symposium on Postharvest Physiology of Ornamental Plants 543: 337-342.

[71] Solanke, A. U., Sharma, A. K. (2008): Signal transduction during cold stress in plants. Physiology \& Molicular Biology of Plants 14: 69-79.

[72] Soni, S. S., Godara, A. K. (2017): Evaluation of Gerbera Varieties for Growth and Floral Characters Grown Under Greenhouse Condition. - Journal of Current Microbiology and Applied Sciences 6: 2740-2745.

[73] Sood, S., Vyas, D., Nagar, P. K. (2006): Physiological and biochemical studies during flower development in two rose species. - Scientia Horticulturea 108: 390-396.

[74] Streck, N. A. (2004): A temperature response function for modeling leaf growth and development of the African violet (Saintpaulia ionantha Wendl.). - Ciência Rural 34: 5562.

[75] Sudhakar, M., Kumar, S. (2015): Studies on the influence of planting season and weather parameters on growth parameters of two different varieties of G. grandiflorus L. - Asian Journal of Horticulture 10: 36-40.

[76] Thakur, P., Kumar, S., Malik, J. A., Berger, J. D., Nayyar, H. (2010): Cold stress effects on reproductive development in grain crops: an overview. - Environmental \& Experimental Botany 67: 429-443.

[77] Usha, B. T., Chandara Sekhar, R., Reddy, Y. (2002): Vase life studies of three gladiolus cultivars as influenced by dates of planting and iron sulphate sprays. - The Journal of Research Angrau 30: 40-43.

[78] van Doorn, W. G., Woltering, E. J. (2004): Senescence and programmed cell death: substance or semantics? - Journal of Experimental Botany 55: 2147-2153.

[79] von Caemmerer, S., Evans, J. R. (2015): Temperature responses of mesophyll conductance differ greatly between species. - Plant, Cell \& Environment 38(4): 629-637.

[80] Waraich, E. A., Ahmad, R., Halim, A., Aziz, T. (2012): Alleviation of temperature stress by nutrient management in crop plants. - Journal of Soil Science and Plant Nutrition 12(2): 221-244.

[81] Warren, C., Dreyer, E. (2006): Temperature response of photosynthesis and internal conductance to $\mathrm{CO}_{2}$ : results from two independent approaches. - Journal of Experimental Botany 57: 3057-3067.

[82] Zheng, Y. L., Feng, Y. L., Lei, Y. B., Yang, C. Y. (2009): Different photosynthetic responses to night chilling among twelve populations of Jatropha curcas. - Photosynthetica 47: 559-566. 